\title{
Effective Supervision from Research Students' Perspective
} \author{
Zulkifli A. Manaf ${ }^{1} *$ \\ *Correspondence: University Sultan Zainal Abidin \\ Gong Badak Campus, 21300 Kuala Terengganu \\ Terengganu, Malaysia \\ E-mail:izah@unisza.edu.my \\ ${ }^{1}$ *University Sultan Zainal Abidin \\ Gong Badak Campus, 21300 Kuala Terengganu \\ Terengganu, Malaysia
}

Izah Mohd Tahir*, Norizan Abdul Ghani ${ }^{1}$, Engku Suhaimi Engku Atek ${ }^{1} * \&$

E-mail:norizabd@unisza.edu.my; esuhaimi@unisza.edu.my; zulkflimanaf@unisza.edu.my

Received: March 18, 2012 Accepted: June 14, 2012 Published: June 24, 2012

doi:10.5296/ije.v4i2.1531 URL: http://dx.doi.org/10.5296/ije.v4i2.1531 


\title{
Macrothink
}

\begin{abstract}
There are many factors that determine the success of research students in doing their postgraduate programs. Of these are the supervisors and effective supervision. The aim of this paper is to identify the attributes of supervisors and examine elements of effective supervision from the graduate research students' perspective. In addition, the study also examines whether the means of the students' opinions on their supervisors and effective supervision differ by demographic factors (program, faculty, course structure, gender and semester). Descriptive statistics will be used to describe the sample and Pearson chi-square test will be employed to test students' opinions on their supervisors and effective supervision and their relationships with demographic factors. Our results suggest that the three most important attributes of supervisors are: supervisors should be friendly, approachable and flexible; knowledgeable and resourceful; and encourage students to work and plan independently. In addition, the results indicate that effective supervision means that supervisors are able to establish good and professional relationships with students; give support and guidance; and provide continuous motivation and inspiration. Using Pearson chi-square test, the results suggest that there are no significant differences in means between attributes of supervisors and effective supervision based on program, faculty, course structure, gender and semester.
\end{abstract}

Keywords: supervisors, effective supervision, graduate research students, friendly, approachable 


\section{Introduction}

Students pursue their masters or doctoral programs for various reasons. These reasons include to improve career opportunities; for promotion; to gain social status and even self development (Zaitun, 2010). Effective supervision has been empirically proven to be one of the elements of success factors for postgraduate research students (Cullen et. al. 1994, Buttery and Richter 2005, Abiddin 2007). The structure of supervisions depends on the guidelines provided by the individual universities. Generally, there three structures of supervision; single supervisor, two supervisors (main and co-supervisor) and a committee consisting of at least three supervisors and one acts as the chairperson. The relationship between student and a supervisor is essential as it is one of the factors that will affect the progress of research students and eventually their completion. Abiddin and West (2007, page 370) postulated that "without good supervision from a good supervisor, problematic situations will arise which can affect progress". Thus, we can conclude that good supervision is one of the factors that will ensure the success of the research students in completing their studies.

The present study explores what are the attributes of good supervision. It examines the attributes of supervisors and elements of good supervision from the graduate students' perspective. This study is carried out in one of the public university in Malaysia, University Sultan Zainal Abidin. Graduate Management Centre University Sultan Zainal Abidin was established in July 2007 offering Masters and Doctoral programme by research only. The first intake of 10 Masters Students was made in December 2007. As at February 2012, there are 185 postgraduate students, 134 registered as Masters Students and 51 as doctoral students. Currently, three Masters Students have graduated and we have yet to see doctoral student to graduate.

\section{Objective}

The objective of this study is to examine the attributes of supervisors and elements of good supervision from the graduate students' perspective.

\section{Research Questions}

Accordingly, this study addresses the following research questions:

1) What are the perceptions of students of their supervisors?

2) What are elements of effective supervision?

3) Do opinions on supervisors' attributes and effective supervision differ by program, faculty, course structure, gender and semester?

\section{Literature Review}

Good supervision from a good supervisor is important because that would assist research students to carry out the research and produce output at the end of the given time frame. Therefore, good supervisors must possess certain characteristics. According to Cullen et al. 
(1994), as part of a major study carried out at the Australian National University, Canberra, the characteristics of a 'good supervisor' are as follows:

1) approachable and friendly;

2) supportive, positive attitude;

3) open minded, prepared to acknowledge error;

4) organised and thorough; and

5) Stimulating and conveys enthusiasm for research.

Study by Cullen et al (1994, page 108) concluded that:

The identification of effective supervisory practice was best accomplished not through the simple aggregation of existing best practice, but rather through the deconstruction of supervisory practice and through the identification of those aspects of supervisory practice which would most benefit from strengthening, elaboration or change.

In a more recent study, it was found that good relationship between student and supervisor will ensure research project is complete successfully. Effective supervisor is essential in the study process and enhance research progress (Abiddin et al. 2011).

In a previous study done by Abiddin in 2006, which focused on the support and practices on supervision and experiences of foreign $\mathrm{PhD}$ students in $\mathrm{UK}$ found that, supervisor needs to adopt different modes of supervision. The study also found that in Science disciplines, it is best to have two meetings with supervisor and the supervisor, department and students are responsible for the success of a students' research.

Apart from that the quality of postgraduate depends not only on the supervision methodology but also other elements which include policies, infrastructure, funding, library, computing, office space, conferences, travels, fieldwork and so on (Buttery and Richter, 2006). Furthermore, interactions, quality, style of supervision, role expectations of students and supervisors are jointly important (Kam, 1997).

The paper discusses characteristics of a supervisor which include expertise in the research area, support for the student, balancing creativity and criticism that were highlighted in previous studies done by Fraser and Matthews (1999).

Good supervisors should have the following characteristics: approachable and friendly; supportive, positive attitude; open minded, prepared to acknowledge error; organized and thorough; and stimulating and conveys enthusiasm for research (Cullen et al., 1994).

Therefore in this current study the research team focused on identifying the characteristics of good supervisors and the quality of their supervision from the client's perspectives that is the graduate students themselves. This is reflected by the research questions posited and the various items presented in the instrument of the study. 
James and Baldwin (1999) suggested eleven practices of effective supervisors. These are:

1) Ensure the partnership is right for the project;

2) Get to know the students and carefully assess their needs;

3) Establish reasonable, agreed expectations;

4) Work with students to establish a strong conceptual structure and research plan

5) Encourage students to write early and often;

6) Initiate regular contact and provide high quality feedback;

7) Get students involved in the life of the department;

8) Inspire and motivate

9) Help if academic and personal crises crop up;

10) Take an active interest in students' future careers; and

11) Carefully monitor the final production and presentation of the research.

From here we can see that supervisors play an important role in the academic life of the students as well as personal careers. Supervisors are the motivators and problem solvers.

\section{Methodology}

The questionnaires used for this study were adopted from previous research. The questionnaires were divided into three sections. Section $\mathrm{A}$ is the demographic profiles of respondents. The demographics include, gender, program, faculty, course structure, nationality and year. Section B is on the characteristics of a supervisors and Section C relates to elements of effective supervision. These items were measured using a 5-point, Likert-type format with the following anchors: $1=$ strongly disagree, $2=$ disagree, $3=$ neutral, $4=$ agree and $5=$ strongly agree.

Coded responses were analysed using the Statistical Packages for the Social Sciences. Means was used to describe the level of agreement among the statements asked. Pearson $\chi^{2}$ tests procedures were applied to the data set to test whether the mean of the students' opinions on their supervisors and effective supervision differ by program, faculty, course structure, gender and semester.

Cronbach's alpha values were calculated for dimensions on opinions regarding supervisor and effective supervision. This is shown in Table 1. The alpha's values show that the items used are appropriate and both have $\alpha$ value of more than 90 percent. 


\section{Macrothink}

Table 1: Cronbach's Alpha Values for Items Used

\begin{tabular}{clcc}
\hline Sections & Dimensions & $\begin{array}{c}\text { Cronbach's Alpha } \\
\text { Value }\end{array}$ & Items \\
\hline B & Opinions Regarding Your Supervisor & 0.972 & 21 \\
C & Opinions Regarding Effective Supervision & 0.967 & 21 \\
\hline
\end{tabular}

This study is carried out in December 2010. Of the 132 students enrolled for Masters and $\mathrm{PhD}$ degrees in 2010, 100 respondents answered the questionnaires and 63 were usable for analysis giving a response rate of 63 percent.

Table 2 presents the results on the demographic profiles of the respondents participated in this survey. $52 \%$ of the survey samples were female and the rest were male. Of this majority or $77.8 \%$ were doing Master program. These students were from the Faculty of Business Management and Accountancy (14.3\%), Faculty of Islamic Contemporary Studies (36.5\%), Faculty of Agriculture and Biotechnology (27\%), Faculty of Languages and Communication $(7.9 \%)$ and faculty of Informatics (3.2\%). Since, UniSZA is still considered a new university; the number of foreign students was very small.

Table 2: Demographic Profiles of Respondents

\begin{tabular}{|c|c|c|c|c|c|c|}
\hline Variables & & & Catec & ories & & \\
\hline & Male & Female & & & & \\
\hline Gender & 52.4 & 47.6 & & & & \\
\hline & Master & $\underline{P h D}$ & & & & \\
\hline Program & 77.8 & 22.2 & & & & \\
\hline & Busines & Islamic & Biotechnolo & Medica & Lanquage & Informatics \\
\hline & $\underline{\mathbf{s}}$ & & gy & $\underline{I}$ & $\underline{\mathbf{s}}$ & \\
\hline Faculty & 14.3 & 36.5 & 27.0 & 11.1 & 7.9 & 3.2 \\
\hline & Full time & $\frac{\text { Part }}{\text { time }}$ & & & & \\
\hline Course & & & & & & \\
\hline Structure & $\begin{array}{c}57.1 \\
\text { Malaysia } \\
\end{array}$ & $\begin{array}{c}42.9 \\
\text { Foreign } \\
\end{array}$ & & & & \\
\hline $\begin{array}{l}\text { Nationalit } \\
\text { y }\end{array}$ & $\frac{\mathbf{n}}{98.4}$ & 1.6 & & & & \\
\hline Year & $\frac{1}{27.0}$ & $\begin{array}{c}\mathbf{2} \\
34.9\end{array}$ & $\underline{\mathbf{3}}$ & $\underline{\underline{4}}$ & & \\
\hline
\end{tabular}

\section{Findings}

\subsection{Graduate Students' Perceptions of their Supervisors}

In this section, 21 statements were asked to the respondents. Table 3 presents the descriptive statistics for all the items on supervisors' attributes under investigation. All the 
statements are positive and significant at $<0.01$. The most important attributes are with statement no. 8: "My supervisor is friendly, approachable and flexible". This finding is consistent to the findings by Cullen et al. (1994) and Abiddin and West (2007). The second most favourable response is statement no. 7: "My supervisor was knowledgeable and resourceful", followed by statement no. 10: "My supervisor encourages me to plan and work independently". Abiddin and West (2007) found that the second of importance are related to statement: "My supervisor is an active researcher in the discipline"; followed by statement: "My supervisor is an effective communicator".

Table 3: Descriptive Statistics of the students' perception of their Supervisors

\begin{tabular}{llccc}
\hline No & Statements & Mean & SD & Rank \\
\hline 1 & Has research interest that are similar to mine & 4.48 & 0.84 & 16 \\
2 & Is interested and supportive to my research & 4.65 & 0.69 & 5 \\
3 & Guides and points me to the source of the relevant & 4.37 & 0.81 & 19 \\
& literature in the discipline & & & \\
4 & Assists me in conceptualizing the research project & 4.51 & 0.76 & 13 \\
5 & Provides critical feedback and feed forward on my written & 4.51 & 0.76 & 12 \\
& work & & & \\
6 & Is available when needed for project discussion & 4.59 & 0.69 & 9 \\
7 & Is knowledgeable and resourceful & 4.70 & 0.67 & 2 \\
8 & Is friendly, approachable and flexible & 4.71 & 0.66 & 1 \\
9 & Has research management and leadership skills & 4.65 & 0.68 & 4 \\
10 & Encourages me to plan and work independently & 4.68 & 0.62 & 3 \\
11 & Ensures that I meet the deadlines & 4.41 & 0.82 & 17 \\
12 & Is an active researcher in the discipline & 4.59 & 0.78 & 11 \\
13 & Leads and investigates in choosing the research topic & 4.59 & 0.73 & 10 \\
14 & Has excellent interpersonal skills & 4.62 & 0.71 & 6 \\
15 & Has vast and varied experience in research & 4.60 & 0.66 & 8 \\
16 & Has vast and varied supervision experience & 4.51 & 0.78 & 15 \\
17 & Has good working knowledge of various research & 4.51 & 0.72 & 14 \\
& methodology & & & \\
18 & Has a good command of using statistical software for data & 3.97 & 0.89 & 21 \\
& analysis & & & \\
19 & Has a good command in the use of appropriate software in & 4.00 & 0.86 & 20 \\
20 & qualitative data analysis & & & \\
& Has a lot of professional affiliations with other research & 4.38 & 0.75 & 18 \\
21 & Has good writing skills & 4.60 & 0.64 & 7 \\
\hline Note: SD = Standard Deviation & & & \\
\hline
\end{tabular}

On the other hand, the three least of importance are related to statement no. 3: "My supervisor guides and points me to the source of the relevant literature in the discipline"; statement no. 19: "My supervisor has a good command in the use of appropriate software in 
qualitative data analysis"; and statement no. 18: "My supervisor has a good command of using statistical software for data analysis".

\subsection{Students' opinions on Effective Supervision}

Section $\mathrm{C}$ of the questionnaire addressed the elements of effective supervision from the students' perspective. There are twenty one questions in this section. Table 4 presents the results. Accordingly, students perceived that the most important element in effective supervision was related to statement no. 7: "effective supervisor should establish good and professional relationships with the student"; followed by statement no. 1: "Effective supervisor should give support and guidance about the research process and the standards expected". Students also believe that "Effective supervisor should provide continuous motivation and inspiration". However, it is quite surprising that students ranked statements no. 10: "Keep a written record of the content of the meetings" and no. 9: "Schedule regular meeting to monitor student progress", as the least importance. These statements are related to regular meetings and keeping records on the meetings that had taken place.

Table 4: Descriptive Statistics of Effective Supervision

\begin{tabular}{|c|c|c|c|c|}
\hline No & Statements & Mean & SD & Rank \\
\hline 1 & $\begin{array}{l}\text { Give support and guidance about the research process and the } \\
\text { standards expected }\end{array}$ & 4.73 & 0.60 & 2 \\
\hline 2 & Provide continuous motivation and inspiration & 4.71 & 0.58 & 3 \\
\hline 3 & Occasionally serve as mentor and coach in my project & 4.60 & 0.66 & 12 \\
\hline 4 & Provide personal counselling whenever need arises & 4.67 & 0.67 & 7 \\
\hline 5 & Ensure that the proposed research is manageable and achievable & 4.68 & 0.62 & 6 \\
\hline 6 & $\begin{array}{l}\text { Request written work as appropriate and provide prompt feedback with } \\
\text { constructive criticism within a reasonable time }\end{array}$ & 4.54 & 0.72 & 14 \\
\hline 7 & Be able to establish good and professional relationships with student & 4.76 & 0.53 & 1 \\
\hline 8 & Be accessible whenever needed & 4.62 & 0.75 & 10 \\
\hline 9 & Schedule regular meeting to monitor student progress & 4.40 & 0.77 & 21 \\
\hline 10 & Keep a written record of the content of the meetings & 4.46 & 0.71 & 20 \\
\hline 11 & $\begin{array}{l}\text { Act as a guide on research and generic skills which the student should } \\
\text { acquire and how this might be done }\end{array}$ & 4.63 & 0.58 & 9 \\
\hline 12 & $\begin{array}{l}\text { Provide appropriate opportunity for the student to talk about his or her } \\
\text { work in graduate seminars }\end{array}$ & 4.62 & 0.66 & 11 \\
\hline 13 & Identify meetings, courses, conference and training opportunities & 4.48 & 0.69 & 19 \\
\hline 14 & $\begin{array}{l}\text { Ensure that the student is made aware of inadequacy of his/her } \\
\text { progress or his/her standard work is below what is generally expected }\end{array}$ & 4.51 & 0.64 & 16 \\
\hline 15 & $\begin{array}{l}\text { Set deadlines for submission of particular parts of the thesis within the } \\
\text { scheduled time }\end{array}$ & 4.51 & 0.74 & 17 \\
\hline 16 & $\begin{array}{l}\text { Provide assistance in orientating students towards appropriate } \\
\text { behaviour in oral examination }\end{array}$ & 4.54 & 0.67 & 15 \\
\hline 17 & Provide a good example as a leader & 4.70 & 0.59 & 5 \\
\hline 18 & Supervise students according to their ability and individual requirements & 4.67 & 0.60 & 8 \\
\hline 19 & Should have significant knowledge and experience in the field & 4.71 & 0.66 & 4 \\
\hline 20 & $\begin{array}{l}\text { Get students involve the activities and life of } \\
\text { department/faculty/postgraduate centre }\end{array}$ & 4.49 & 0.78 & 18 \\
\hline 21 & Take an active interests in student future careers & 4.56 & 0.74 & 13 \\
\hline
\end{tabular}




\section{Macrothink}

International Journal of Education ISSN 1948-5476 2012, Vol. 4, No. 2

4.3 Relationship between graduate student perceptions towards Supervisors and Demographic Factors

To examine the relationship between graduate students perceptions towards supervisors and demographic factors of the respondents (program, faculty, structure of course, gender and semester), chi-square was computed. This test was used to see whether there were any significant differences in response, since there were different groups involved in the study. The results are shown in Table 5.

Table 5: Supervisors and Demographic Factors (Pearson one-way ANOVA)

\begin{tabular}{|c|c|c|c|c|c|c|c|c|c|c|}
\hline \multirow[t]{2}{*}{ Items } & \multicolumn{2}{|c|}{ Program } & \multicolumn{2}{|c|}{ Faculty } & \multicolumn{2}{|c|}{$\begin{array}{l}\text { Structure } \\
\text { of Course }\end{array}$} & \multicolumn{2}{|c|}{ Gender } & \multicolumn{2}{|c|}{ Semester } \\
\hline & $x^{2}$ & Sig. & $x^{2}$ & Sig. & $x^{2}$ & Sig. & $x^{2}$ & Sig. & $x^{2}$ & Sig. \\
\hline 1 & 1.546 & 0.672 & 16.037 & 0.380 & 2.942 & 0.401 & 3.252 & 0.354 & 11.940 & 0.941 \\
\hline 2 & 1.693 & 0.638 & 10.093 & 0.814 & 1.420 & 0.701 & 0.946 & 0.814 & 17.543 & 0.678 \\
\hline 3 & 1.846 & 0.605 & 6.664 & 0.966 & 0.731 & 0.866 & 3.952 & 0.267 & 19.723 & 0.539 \\
\hline 4 & 2.488 & 0.477 & 10.776 & 0.768 & 6.506 & $0.089^{c}$ & 4.438 & 0.218 & 19.602 & 0.547 \\
\hline 5 & 0.456 & 0.928 & 10.843 & 0.764 & 4.204 & 0.240 & 1.222 & 0.748 & 17.020 & 0.710 \\
\hline 6 & 3.925 & 0.270 & 17.753 & 0.276 & 1.699 & 0.637 & 4.716 & 0.194 & 15.246 & 0.810 \\
\hline 7 & 8.933 & $0.030^{b}$ & 21.418 & 0.124 & 5.752 & 0.124 & 2.443 & 0.486 & 17.038 & 0.709 \\
\hline 8 & 0.479 & 0.923 & 10.734 & 0.771 & 4.258 & 0.235 & 6.334 & 0.096 & 20.767 & 0.473 \\
\hline 9 & 1.833 & 0.608 & 13.391 & 0.572 & 1.560 & 0.668 & 7.167 & 0.067 & 12.233 & 0.933 \\
\hline 10 & 1.985 & 0.576 & 11.016 & 0.751 & 4.457 & 0.216 & 0.958 & 0.812 & 19.876 & 0.529 \\
\hline 11 & 3.466 & 0.325 & 18.627 & 0.231 & 7.056 & $0.070^{c}$ & 4.156 & 0.245 & 32.767 & $0.049^{b}$ \\
\hline 12 & 1.848 & 0.605 & 14.365 & 0.498 & 3.561 & 0.313 & 4.014 & 0.260 & 17.989 & 0.650 \\
\hline 13 & 3.596 & 0.308 & 16.271 & 0.364 & 7.278 & $0.064^{c}$ & 6.014 & 0.111 & 16.463 & 0.743 \\
\hline 14 & 1.761 & 0.624 & 17.251 & 0.304 & 3.201 & 0.362 & 3.103 & 0.376 & 21.316 & 0.440 \\
\hline 15 & 5.347 & 0.148 & 15.343 & 0.427 & 5.899 & 0.117 & 1.467 & 0.690 & 19.654 & 0.543 \\
\hline 16 & 2.973 & 0.396 & 20.969 & 0.138 & 2.990 & 0.393 & 1.360 & 0.715 & 16.950 & 0.714 \\
\hline 17 & 0.316 & 0.957 & 12.908 & 0.609 & 2.102 & 0.551 & 6.458 & 0.091 & 13.149 & 0.903 \\
\hline 18 & 0.816 & 0.846 & 20.041 & 0.170 & 4.569 & 0.206 & 4.383 & 0.223 & 24.139 & 0.286 \\
\hline 19 & 0.622 & 0.891 & 16.606 & 0.343 & 9.222 & $0.026^{b}$ & 0.479 & 0.924 & 20.220 & 0.507 \\
\hline 20 & 1.874 & 0.599 & 10.896 & 0.760 & 4.764 & 0.190 & 7.463 & 0.059 & 22.842 & 0.352 \\
\hline 21 & 1.194 & 0.754 & 13.701 & 0.548 & 4.213 & 0.239 & 4.964 & 0.174 & 19.014 & 0.584 \\
\hline
\end{tabular}

The reported chi-square showed that as an overall, there were no significant differences in means between graduate students' perceptions towards supervisors based on program, faculty, structure of course, gender and semester. This indicates that graduate students' perceptions towards their supervisors are similar regardless of program, faculty, structure of course, gender and semester. 
4.4 Relationship between graduate student perceptions towards Effective Supervision and Demographic Factors

We also examine the relationship between graduate students' perceptions on effective supervision based on program, faculty, structure of course, gender and semester using Pearson chi-square test. The results are presented in Table 6.

Table 6: Effective Supervision and Demographic Factors (Pearson one-way ANOVA)

\begin{tabular}{|c|c|c|c|c|c|c|c|c|c|c|}
\hline \multirow[t]{2}{*}{ Items } & \multicolumn{2}{|c|}{ Program } & \multicolumn{2}{|c|}{ Faculty } & \multicolumn{2}{|c|}{$\begin{array}{l}\text { Structure } \\
\text { of Course }\end{array}$} & \multicolumn{2}{|c|}{ Gender } & \multicolumn{2}{|c|}{ Semester } \\
\hline & $x^{2}$ & Sig. & $x^{2}$ & Sig. & $x^{2}$ & Sig. & $x^{2}$ & Sig. & $x^{2}$ & Sig. \\
\hline 1 & 5.837 & 0.120 & 9.263 & 0.863 & 1.423 & 0.700 & 2.543 & 0.468 & 20.091 & 0.515 \\
\hline 2 & 4.670 & 0.198 & 13.034 & 0.600 & 2.797 & 0.424 & 2.639 & 0.451 & 18.562 & 0.613 \\
\hline 3 & 0.613 & 0.893 & 22.338 & $0.099^{c}$ & 2.233 & 0.526 & 2.219 & 0.528 & 12.522 & 0.924 \\
\hline 4 & 7.096 & $0.069^{c}$ & 22.524 & $0.095^{c}$ & 3.724 & 0.293 & 1.861 & 0.602 & 19.843 & 0.531 \\
\hline 5 & 1.985 & 0.576 & 8.406 & 0.906 & 1.479 & 0.687 & 0.958 & 0.812 & 22.024 & 0.398 \\
\hline 6 & 3.090 & 0.378 & 9.271 & 0.863 & 2.925 & 0.403 & 1.084 & 0.781 & 20.718 & 0.476 \\
\hline 7 & 1.286 & 0.526 & 7.703 & 0.658 & 1.355 & 0.508 & 1.193 & 0.551 & 11.942 & 0.611 \\
\hline 8 & 1.349 & 0.718 & 11.035 & 0.750 & 7.372 & $0.061^{c}$ & 2.283 & 0.516 & 18.180 & 0.638 \\
\hline 9 & 3.604 & 0.308 & 13.027 & 0.600 & 3.581 & 0.310 & 1.442 & 0.696 & 16.521 & 0.740 \\
\hline 10 & 4.146 & 0.246 & 12.587 & 0.634 & 2.748 & 0.432 & 1.219 & 0.749 & 20.934 & 0.463 \\
\hline 11 & 1.231 & 0.540 & 8.125 & 0.617 & 1.400 & 0.497 & 1.756 & 0.416 & 8.672 & 0.851 \\
\hline 12 & 8.334 & $0.040^{b}$ & 10.480 & 0.789 & 2.585 & 0.460 & 1.351 & 0.717 & 13.634 & 0.885 \\
\hline 13 & 4.295 & 0.231 & 8.779 & 0.889 & 1.936 & 0.586 & 3.036 & 0.386 & 15.382 & 0.803 \\
\hline 14 & 1.446 & 0.695 & 8.260 & 0.913 & 1.693 & 0.638 & 1.639 & 0.651 & 23.189 & 0.334 \\
\hline 15 & 1.262 & 0.738 & 5.302 & 0.989 & 3.605 & 0.307 & 1.527 & 0.676 & 16.728 & 0.727 \\
\hline 16 & 0.655 & 0.884 & 10.210 & 0.806 & 2.148 & 0.542 & 2.226 & 0.527 & 12.300 & 0.931 \\
\hline 17 & 3.815 & 0.282 & 9.626 & 0.843 & 3.357 & 0.340 & 2.169 & 0.538 & 22.991 & 0.344 \\
\hline 18 & 3.246 & 0.355 & 11.049 & 0.749 & 3.474 & 0.324 & 6.427 & $0.093^{c}$ & 19.822 & 0.533 \\
\hline 19 & 5.259 & 0.154 & 10.640 & 0.778 & 4.690 & 0.196 & 3.345 & 0.341 & 13.596 & 0.886 \\
\hline 20 & 2.544 & 0.467 & 7.328 & 0.948 & 3.402 & 0.334 & 6.088 & 0.107 & 17.036 & 0.709 \\
\hline 21 & 2.612 & 0.455 & 11.637 & 0.706 & 8.750 & $0.033^{b}$ & 2.541 & 0.468 & 20.442 & 0.493 \\
\hline
\end{tabular}

The reported chi-square showed that as an overall, there were no significant differences in means between student perceptions towards effective supervision based on program, faculty, structure of course, gender and semester.

\section{Conclusion}

Supervisors play an important role in the academic life of the students as well as personal careers. They should possess certain characteristics, not only personal characteristics but also characteristics which are relevant to the interests of doing research with the students. Based on the information gathered from the data analysis, the following conclusion could be 
made regarding the responses from the sample used in this study towards attributes of a good supervisor.

1) Supervisors should be friendly, approachable and flexible as well knowledgeable and resourceful

2) Effective supervision means be able to establish good and professional relationships with students and are able to support and guide during the research process

3) There were no significant differences in means between student perceptions towards their supervisors and effective supervision based on program, faculty, structure of course, gender and semester.

Our findings on effective supervision are consistent to that found by Cullen et al., (1994). They posit that good supervisors should be approachable and friendly; supportive, positive attitude; open minded, prepared to acknowledge error; organized and thorough; and stimulating and conveys enthusiasm for research.

This useful information should be useful in workshops and seminars or modules to train new supervisors so that they will be aware of the prerequisites and demands in effective graduate student supervision. While it is also relevant refresher to existing supervisors, the most important thing is that the information is based on empirical research.

\section{References}

Abiddin N Z. (2006). Effective Supervision of Research Students: A study of University Practices and foreign Students' Experiences. The Journal of Human Resource and Adult Learning, May, 97-107.

Abiddin N Z. (2007). Postgraduate Students" Perception on Effective Supervision: A Case Study at One Public University in Malaysia. The Journal of International Social Research, 1/1 fall, 7-19.

Abiddin N Z., and West M. (2007). Effective Meeting in Graduate Research Student supervision. Journal of Social Sciences, 3(1), 27-35. http://dx.doi.org/10.3844/jssp.2007.27.35

Abiddin N Z., and West M. (2007). Supervision Practices for Foreign Graduate Research Students. American Journal of Applied Sciences, 4(6), 362-370. http://dx.doi.org/10.3844/ajassp.2007.362.370

Abiddin N. Z., and Ismail A. (2011), Attrition and Completion Issues in Postgraduate Studies for Student Development, International Review of Social sciences and Humanities, 1, $15-29$.

Buttrey E A., and Richter E. M. (2005). An Overview of the Elements that Influence Efficiency in Postgraduate Supervisory Practice Arrangements. International Journal of Educational Management, 19(1), 7-26. http://dx.doi.org/10.1108/09513540510574920 


\section{Macrothink}

International Journal of Education

ISSN 1948-5476 2012, Vol. 4, No. 2

Cullen D. J., Pearson, M., Saha, L. J., and Spear, R. H. (1994). Establishing effective PhD supervision. Canberra: Higher Education Division, Australian Government Publishing Service.

Fraser R., and Mathews A. (1999). An Evaluation of the Desirable Characteristics of a Supervisor. Australian Universities Review, 5-7

James R., and Baldwin G. (1999). Eleven Practices of Effective Postgraduate Supervisors, Centre for the Studies of Higher Education and the School of Graduate Studies, University of Melbourne.

Kam B. H. (2007). Style and Quality in Research Supervision: The Dependency Factor, Higher Education, 34, 81-103. http://dx.doi.org/10.1023/A:1002946922952

Zaitun A. B. (2010). Strategic Cooperation to Enhance Quality in Doctoral Supervision, Paper presented at the Third Conference on Quality in University Education in the Islamic World, Naif Arab University for Security Sciences (NAUSS), Riyadh, 20-11 December.

\section{Copyright Disclaimer}

Copyright reserved by the author(s).

This article is an open-access article distributed under the terms and conditions of the Creative Commons Attribution license (http://creativecommons.org/licenses/by/3.0/). 